and to the purpose of punishment, which is the safeguard of public security, returning to free life men duct. It is not surprising, then, that under different
forms this idea has considerably extended and has modified in this way the prisons of different countries.
With the exception of perhaps Belgium, where the cellular system during all the imprisonment gives good results, I believe there is not a

isolat the side of prisons of continued isolation, which are becoming more rare, we see rising everywhere prisons with a graduated system. In Italy, after some dangerous among the convicts, all have adopted in the ishments. We have also introduced it in the military will admit.

In extending this principle further, in some states
they began to establish conditional punishments for offenses of less gravity ; that is, the condemned under-
goes the punishment only after a second conviction. goes the punishment only after a second conviction.
With regard to judicial prisons, as they are for a deWith regard to judicial prisons, as they are for a de-
tention which should be brief, applied to the accused ing which time it is for the interest of public justice, of public safety, and human dignity, that there be no and those who may not be, every one agrees that the ular separation, although the need of sufficient estabthe system.
It is hardly necessary to add that when once the
idea of reformation enters the penal institution, then idea of reformation enters the penal institution, then
comes the desire either to prevent crime in cutting off
its sources or to hinder as far as possible the relapse of its sources or to hinder as far as possible the relapse of come the reform schools for the young and societies of patronage. Concerning these complementary institutions of prison reform, the first of which in our days
has had a ureat development, I cannot speak now, for
they furtists sufficient material for several conferences. they furrisist sufficient material for several conferences.
After this summary view of the origin and development of penitentiary reform, I request you to follow
me for a short time, so that we can together grasp the me for a short time, so that we can together grasp the appreciate the good results which have been obtained, distinguish what is to be avoided and what is yet to
be accomplished, so that if we cannot fully attain the object sought, we can approach it inore and more.

cone ESSENCE OF PENitentiary ReForm. I consider only those fundamental principles that
are common to all systems, and I understand that the essential unity of prison reform, whatever may be the manner of its application, consists in removing what-
ever the ancient prisons possessed of cruelty, anti-
hygiene and immorality, and to make the punishment hygiene and immorality, and to make the punishment
serve for the reform of the criminal. And I ask, in serve for the reform of the criminal. And this noble end, Have we not lost sight of the
true object of punishment? And in applying this true object of punishment? And in applying this
principle are the means employed adapted to gain the real reform of the guilty ?

real reform of the guilty?
Observe, then, in what manner we may derive profit
from the rapid review we have just made of the prison reform movement. Consider well the subject upon which I shall address you a few moments longer, if you
will give me your kind attention. The condition of ancient prisons, the treatment and
nourishment of prisoners, and their idle congregation
were without doubt highly contrary to the health and werality of the prisoners, and consequently to the
public interests and social security.

Desiring to remedy these evils, we often fall into
the opposite extreme. We have so elaborately at-
tended to the buildings, the cells, the food and the tended to the buildings, the cells, the food and the labor from morning to night to give a morsel of bread
to their families, if they knew how they would be treated in certain prisons, they would perhaps prefer
-in all save crime-life in the prison to that in their sorry attic.
In some places they are so occupied in perfecting
their prisons by the best methods of ventilation, heating, pavements, furniture, locks, supervision and a thousand other details that the essential end of reform, the conversion of the guilty, has imperceptibly
passed to a second place. On the contrary, push-
ing to the extreme the principle of moral reform. it is claimed that so long as the prisoner is unchanged he should remain in confinement. It would be usefore the reformation is complete, and the punishment would not be effective, even for public safety, if we re-
turned to society a criminal who would commit new offenses.

In the mean time the great public, seeing these ex-
aggerations, and not seeing much good fruit in those who go out from the prisons, noticing at the same
time the increase of crime, and that crime is frequently a profession, the exercise of which is only interrupted a profession, the exercise of which is only interrupted
from time to time some months of the year when the
offenders are in prison, cry out, smiling, that all this
is but a Utopian theory, pity for rascals to the detri-
ment of honest people. ment of honest people.
On the other hand, the positive school, of which the essential principle is fatalism, founded upon the con- having intrinsic curative powers. It then follows that
ditions of a-man's organization, innate or hereditary, there should be a qualified physician who can arply
upon his social surroundings ; the locality of his birth the remedy to the individual case, and finally that the upon his social surroundings; the locality of his birth the remedy to the individual case, and finally that thi
and education; upon the impelling causes that sick should accept the remedy. Without these condidetermine his actions; sees in all these efforts for visionaries. And if, in view of public safety, we oc-
cupy ourselves with the regime of prisons for the ben-
efit of individual convicts, they see in the criminal only an invalid or an idiot for whom the hospital rather than the prison is the more suitable home.
And, after all, on which side is the truth ? I will first say that I am not one of those who despise as of man, the condition of his organization, the society
where he lives, and the circumstances in which he finds himself. So considerable a part of the human being as is the cian is, above all, the director of the prison, and he
organization of the body, which is the covering and ought to be. Entering with a loving and devoted \begin{tabular}{l|l} 
nstrument of his activity and moral actions, cannot be & $\begin{array}{l}\text { spirit the place of each convict, seeking to possess his } \\
\text { et aside when we must estimate the moral value and } \\
\text { confidence, laboring with each according to his dispo- }\end{array}$ \\
sime imputability of his actions. Two horsemen equally & sition better than any one else he can contribute to
\end{tabular} competent in horsemanship can mount, one an excel- the awakening of the conscience. The pivot of prison ent horse and the other a sorry jade. If I am obliged reform is a good personal direction. But the most to live in an unhealthy place, no one can consider it essential and difficult thing is that the diseased-that
breathes on my part if I am not as well as he who is to say, the prisoner-shall consent to take the rem-
breathes the pure air and oxygen of The mountains.

The influence even of the bad horse can be such that uence of a sickly climate can sometimes force me to Now, all this can prevent the man from acting with
entire freedom, but it does not destroy liberty itself. It is only necessary to say that it will require great least to some extent, the deleterious effect of certain Moral liberty, thous.

narrowed in its exercise, almanagement and more vigorous efforts it can, to a upon this slight liberty we must act to secure the imwell tame men. thing, that the ancient prisons were frightful and unhealthy habitations, where the criminal stagnated in
idleness and filth, where he was poorly fed, and was
under the arbitrary power of guards and directors. Now that he has a proper prison and healthy food but necessary, in the interest of the criminal himself ideration of the fact that under certain circumstances pleted, you return to society a miserable invalid, incapable of earning his bread, and in addition to the he will find the greatest yet-his inability to get work,
which, nine times out of ten, will cause him to commit new crimes. Besides, a good hygienic treatment, wenders him less irritable and predisposes him to men-
tal struggle to improve himself morally. But everv ne can see that this self-treatment is powerless to se-
cure the complete reform of the prisoner. Humane treatment is necessary in order not to de
troy or degenerate his vitality. At the same time stroy or degenerate his vitality. At the same time,
we must never forget that according to the immutable
law of our being, every penalty entails suffering without which man will never apply himself to the practice of virtue for which his natural inclination is 30
feeble. By it he will see it is for his own good in Finally, it is necessary that the condemned endur He should not be treated with cruelty, but he shoul He should not be treated with cruelty, but he should
feel the pain. I will say that the reformation of the
guilty, considered in itself, is a thing to be regarded as it must not be forgotten that it cannot be the direct end of punishment, however desirable it may be. Soby crime, and for that purpose it can do nothing better than to proportion each penalty to each crime. Dur-
ing the execution of the sentence as much as possible
should be done to reform the prisoner, but when the term is ended society no longer has the right to rewise society becomes an agent for morals and educawould the lier be impossible. since even for the smaller
offenses, if the delinquent is not reformed, he might be retained in prison for years and perhaps always weeks, the greatest criminals could be discharged if
they show by their conduct they had reformed. That some endeavor to correct delinquents during their sentence and prevent relapses is very well, but

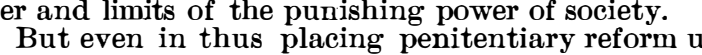
true basis and within true limits, a grave and final question remains to be ans wered. With all this help, A man, although a criminal, does not cease to be a ture. I recall with tender emotion what was said to me some years ago at Christiania by an excellent direct-
or of the prison, loved by all who knew him-Mr. or of the prison, loved by all who knew him-Mr.
"I tersen. "They speak to me of criminals," said he. my soul, I see there, in germ, the same crimes which are punishable in prisons. Only education, religion, vented the germs from developing and prod heing bad ere with himself, is obliged to say. Then the treat ment to apply to the reform of the prisoner is at the
bottom the same as for the moral amendment of the ree man, but there it is necessary to apply it more bstacles arising from vicious tendencies and inveterate

For the efficient treatment of every malady three
hings are necessary. First, that there be a remedy tions no cure is possible.
Now the same thing occurs in the case of the morally
tiseased. For the criminal the first efficient remedy is diseased. For the criminal the first efficient remedy is collection of his offense and made to feel how repul aids him to eradicate those vicious tendencies that reult in crime, and to approach the ideal of a better
lif. In this movement is the essence of the remedy nd secret of reform. Then follows improvement f the morals, which is best promoted by religion, of emedy nor in the physician, but in the patient him-
elf. We build prisons, but what is most difficult is to spirit of man-above all, of the man thoroughly degenerate-there is such a strength of resistance to
reformatory influences that the best efforts fall as Whatever, then, may be the perfections of any prison system that can be conceived, it is inpossible to orm of the prisoner, because there must be a respon-
sive action in his own nature for which a good prison ystem prepares the ground, but no human power can of itself work the cure.
Now as a good general, having met great resistance rom the height of the fortress he has attacked, seeks to enter by a more accessible passage, this inward re-
sistance which is met in consummate criminals has in ation of the young, it being more easy to arrest vice has been an evolution in penal science analogous to the exterior morbid phenomena and applied the remedy to the surface, not preventing the reappearance
of the disease. Then began the study into its causes
and sources, and the search for suitable remedies. But in time it was noticed that the source of the dishabitual ill treatment of the organization in defiance of its natural laws and sickly tendencies, hereditary
or acquired. They then occupied themselves in de-
vising a more rational resjome to maintain or establish the normal and just equilibrium of each force, of each aculty, and of each organ. Medicine thus gravitate plies to the idea of reform as connected with the punishment of the guilty. At first only the gravity of the
injurious results of crime was considered, and they injurious results of crime was considered, and they
inflicted corresponding material punishments, cutting
off the hand of the robber or decapitating the muroff the hand of the robber or decapitating the mur-
derer. Passing later to consider in each case the circumstances of the crime and the degree of guilt chmstances of the crime and the degree of guit
the severity of the punishment to each case and
to each individual. They thought finally to occupy the time of imprisonment for the moral reform At present, seeing the difficulty of the reform of adults, come offenders. Thence comes the development of progress in these later days in houses of reform. Bethe employment of remedies less necessary.
The tendeney of modern legislation toward the mitiThe tendency of modern legislation toward the inti-
gation of punishments requires more energetic action
or prevention. In reform schools lies the hope for the moral reform of the dangerous classes. I dare hope that prison reform, if it shall produce no other benefits, will do immense good by leading many emicriminal youth.
In the meantime we should not neglect to do all In the meantime we should not neglect to do all
that may be to reform the guilty whose sentence has
xpired. Whatever importance is attributed to hygiexpired. Whatever importance is attributed to hygi-
ene, the physician who does not aim to prevent disease, able the disease, is not a good physician.
First, the means employed to reform the criminal do not always fail. There are some prisoners who
reform themselves, and there are sick who heal themelves. when we cannot always succeed? As long as there is life there is hope, and this hope should never" be reut the true aim of all progress is not to reach the end at once, but consists in a constant advance. The reove is never discouraged. When we succeed in prodneing with a few only of the hardened criminals a believe it would be time lost?

It is no small matter to impress on the most de-
graded of society this principle, superior to all differall hearts aspire : the moral redemption of man and of But this moral redemption began in the world by a
power from on high. We should then have faith that power from on high. We should then have faith that
day will come when evil will be vanquished, when a day will come when evil will be vanquished, when
truth, justice and love shall reign here below for the lation of this poor earth.

\section{ACTION OF NITRIC OXIDE UPON THE} METALLIC OXIDES.

By MM. Padl Sabatier and J. B. Senderens. Is a former communication the authors have shown the lower oxides capable of being peroxidized. These oxygen, or by the air, show that nitric oxide has a the peroxides shows that it may also act as a reducing ordinary temperature. Silver oxide is not resolved ide reduces it at $170^{\circ}$ and upward. Lead peroxide, $\mathrm{PbO}_{2}$, if heated alone, is perfectly stable below $450^{\circ}$. it then yields orange minium, which, on prolonged ignition, is converted into yellow litharge. In nitric
oxide the reduction commences about $315^{\circ}$ and proceeds lifhnlarly at this temperature, yielding at once white which evolves oxygen only at a red heat, acts upon oxide. Nitric oxide may be utilized in the production
ond 
of nitriles. The oxide to be experimented upon was
suspended at first in deaerated water by means of suspended at first in deaerated water by means of
washers, traversed at first by a current of hydrogen.
Nitric oxide absolutely free from nitrous vapor is then Nitric oxide absolutely free from nitrous vapor is then
directed upon it, when there is an exclusive formation
of nitriles.-Chem. News.

\section{HIRAM SIBLEY.*}

THE world honors men who have inaugurated great great beginnings of grand social movements. Hiram aibley was one of those who first and most effectively Cornell and his coadjutors and successors that hon or which is perpetuated and symbolized by the material should be given a monument in its chapel, in presThis would be true had he done no more than promote so well the general welfare of the University in man who helped make the fortune which the founder so greatly imperiled later in the effort to sustain his splendid enterprise; the inan who aided so efficiently in making it possible that Cornell University should be founded; who stood hand in hand, shoulder to
shoulder, with the founder during his life, and who, after his dhe liar and noble work to do. He was to make the real beginning of the new and
special "liberal and practical" education, for the privilege of promoting which Cornell paid his hal million dollars and founded his university. He was to which this University was founded especially to promote, and which it has become famous for having so well illustrated in its short life of a quarter of a cenof a great work and which gives Hiram Sibley claim enterprise for which the world had long been waiting, location and under such circumstances, to grow in magnitude and usefulness as long as the fundamental
purpose and the aspirations of the founders of the Uni-
versity should be remembered. The bust in the chapel of Cornell University is unveiled as a testimonial of the respect and affection of his colleagues and of the
authorities of the University. It will stand unchanged through the centuries, and through all the long years will remind coming generations of students and teachof the sturdy form and rugged features of the man
who gained fame and honor as the organizer of a great telegraphic system, but a fame eclipsed by the brightthe sons of the people. After all, the real monument ings and apparatus of scientific research or of practi-
cal work that will most permanently give this man his fame. It is the commencement of the work that con-
stitutes the claim; it will be the constantly growing stitutes the claim; it will be the constantly growing
and never-ending good that comes of it that will raise a monument of constantly increasing magnitude and never-ceasing utility, beside which portrait, bust, or Aristotle founded a philosophy which is to-day of the past; but the founder is honored by the greatest
minds of modern times as a beginner. A great man saw his opportunity to make a beginning; smaller men complete his work. Herodotus wrote a history it was a simply told story; but it was the beginning of
history, and Herodotus still lives. Copernicus, in his knowledge of astronomy, was a child beside the stu-
dent of the stars in our time; but he is immortal as the beginner of a true exposition. Newton began the
development of the science of mechanics; his " Prindevelopment of the science of mechanics; his "Prin-
cipia" is no longer known in the schools; but no that of the man who gathered these pebbles on the that of the man who gathered these pebbles on the of physics and Lavoisier a chemistry, innocent, both, of a knowledge of principles and facts familiar to
every intelligent college lad; their names are forever
famous. Linnaeus and Buffon and Lyell cleared the famous. Linnaeus and Buffon and Lyell cleared the way to merely the portals of the paths of modern and upward. Watt built a first rude steam engine; Stephenson constructed the beginning of the railway; beneath the ground and built the first overhead line, roughly and crudely : but the flash of that first beaumembered longer than bronze or granite shall endure; never need artificial buttress for his intangible monuColumbus discovered America; but his glory is not
bounded by the narrow limits of Watling Island no bounded by the narrow limits of Watling Island, nor is his memory lost in four centuries. Columbus dis-
covered a world, gave foundation to a nation, made a history possible to peoples who, through all time, will
remember him for his share in the beginning of such mighty possibilities. The voyages of Thorstein and of Eric were more hazardous than those of Columbus;
in themselves than the strifes of Columbus; the growth in themselves than the strifes of Columbus ; the growth than the annexation of Mexico or of Peru to Spain; that four hundred years have seen on this continent, and that the coming ages are to see, looms up out of
the historical past in granderand grander proportions a the centuries go by. And thus it is with all famous men. exertions or of the work performed by them in their
own time and by their own strength ; but by the mag. of the results which follow in the years and the cen

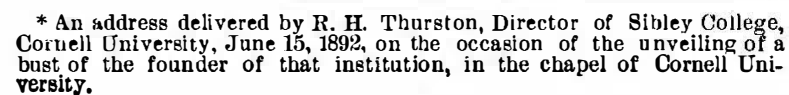

turies which profit by their foresight and wisdom and
self-sacrifice. Thus is it here; and we honor Hiram Sibley to-day;
not because he gave to Cornell University of his troublesome superfluity of wealth; not that he erected struc-
tures that his own State should have raised as her share of the great work inaugurated by the general govern-
ment; not that he made it possible for the nation and mise to the people that neither the State good a promise to the people that neither the State would or the
University otherwise could have at the time fulfilled, though the State had contracted with the general government to do so, and the University was ready to power. He did all this and more; but it is not all this Contributing to Cornell University large sums of ings on her beautiful campus which were needed for the work to which she was pledged; giving opportun the State to secure the most practical and liberal eduation of the time; distributing libraries anong col-
leges, giving schools to the South and the West; aiding the worthy poor in a thousand ways unknown to any eeds of righteousness ; but while entitling the piver to love and honor, they are nevertheless not, in them able fame. We honor Hiram Sibley because, besides
all this, he exhibited a foresight and a grasp in his plan which insured a future and continued growth of generations. The world had just reached a point at ment, in education of the people for the people's needs, anticipated by the wisest men from the earliest days
by Plato, by Aristotle, by Milton, by the Marquis o
Worcester, by Comenius, by Richter, by John Scot

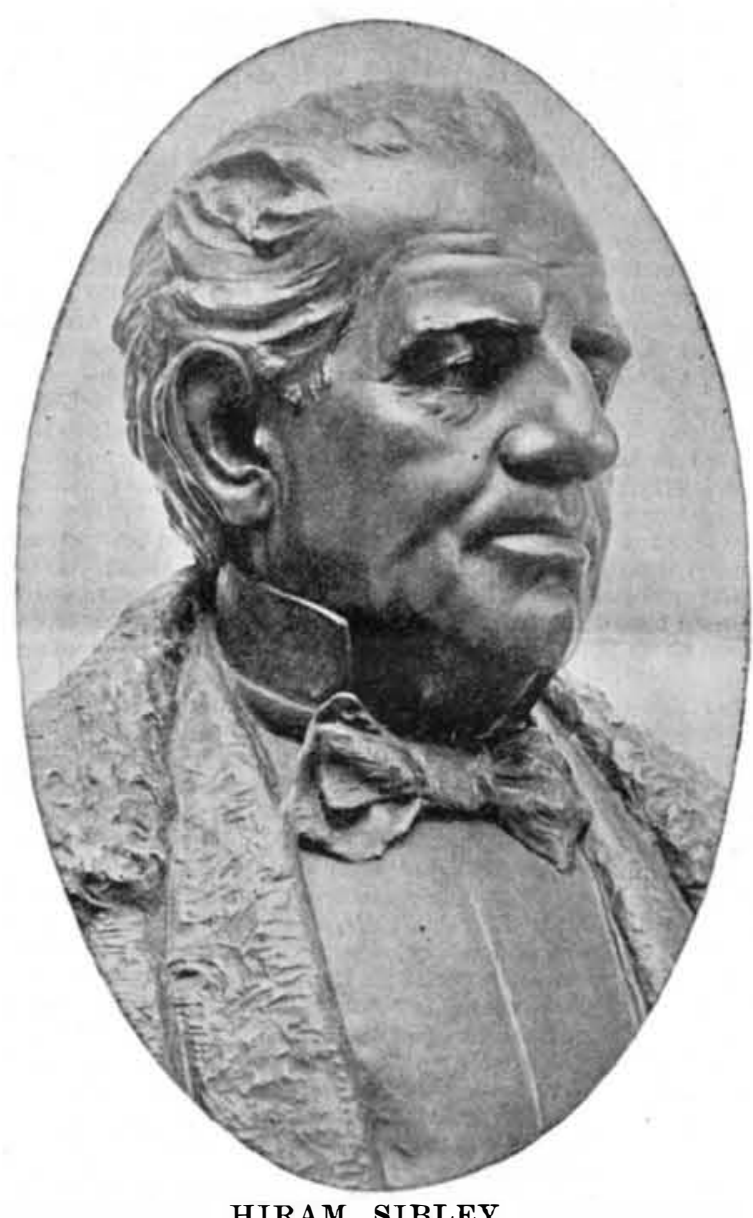

HIRAM SIBLEY.

Russell, and by Van Rensselaer, and Lawrence, an When Era Cornell olled his old antionist business, become his best friend, into the board of opportunity and promptly seized upon it. He took as his share of the work the foundation of the Sibley ColHe stepped into the place of honor and accepted those duties which the state had failed to perform; and Sibley College became the root and the sustaining possibilities as eren the wise man who founded it pro-
bably little realized, even though before his death he had the pleasure of witnessing its first great expansion. adjutor in John L. Morris and his colleagues. He gave adjutor in John L. Morris and his colleagues. He gave the seed, directed its planting, and provided for its and that beginning was thus made for which we here
and now praise and honor the wisdom and liberality of
the man who made it all possible at that time and in this the man who made it all possible at that time and in this
place. He was happy in his opportunity, wise in his ecognition of it, prompt and forceful in his seizure o but beginning to see what that noble work may, if carefully and wisely promoted by his successors and theirs, become. It may easily be made to give to Cor-
nell University the high privilege of becoming the center, for the United States, at least, of all educational
work in these latest departments of a "complete and work in these latest departments of a "complete and ion, the highest of modern and coming times, of here becoming the mainspring of advances in applied science
the source and the support of the grandest develop ments of modern life.
Hiram Sibley lived to see this seed take root, to see far beyond the limits which had been anticipated by far beyond the limits which had been anticipated by
him as possible within his lifetime. He saw it become a sturdy sapling; we have seen it within these few years young tree, splitting its bark in its rapid developmen of new leaves and fresh twigs and wide-spreading
branches and swelling trunk. But not the foresight of the founder himself, not the best judgnent of his of the founder himself, not the best judgnenent of his
shall cease if well cared car wher Give or when its growth shall cease, if well cared for. Give the young tree room or growth, a wholesome soil, and a healthy atmospher in which to expand, and its best friends shall be as and to helpful sympathy by its good fruits and healthul influence. the soil is good and the atmosphere better than is usual; but more space, further enriching of the soil, more
room for the branches, and a still more healthful atroom for the branches, and a still more healthful at-
mosphere are to be hoped for. These given, the value nnd the magnitude world, will never cease to impress more and more every riend of technical and liberal education with its usefulness, its importance, and its growth in all that con stitutes a real basis for the fame of its founder.
Sibley College began twenty years ago as the germ of a struggling school of the mechanic arts, a highe course of instruction, neither an educational course nor a technical course in the full sense of the modern terms. Its students, half educated, half trained professionally, went out into a world less educated, less
well trained, and made their several marks with force and decision, and began effectively to build up the Seven years ago its progress was such as to justify its organization into a technical college of the highest type, and in three years more it had outgrown its seeing it necessary to limit the entering classes while awaiting enlargement of its buildings. This done, he saw, before his death, in the following year, a renewed at least a year above that ordinarily given in such courses, and such that graduates of technical schools in good standing find a full year often necessary for
satisfactory prosecution of their work for the first degree.
To-day, this memorial of our friend, of the founder
of Sibley College, is placed in presence of a hundred Sibley College, is placed in presence of a hundred dred beneficiaries of his noble work. The buildings erected by him, extensive as they are, are more than would be none too much for the coming years of this They are filled to overflowing with the most extensive equipment of its kind in the world, given by Hiram his appreciative successors; yet double this unique outfit could well be utilized to-day, and no one can say what opportunity may come for still larger extension. hundreds of the most ambitious of the young men of Sibley has indeed made a grand beginning, and it now remains for the nation, the State, and all' the friends our time to fittingly supplement his work This great work has another aspect still, which makes it a source of higher honor to Sibley and to his New York accepted the first presidency of Cornell University, he came, not to do the routine work of the hanging institution of classic learning, great and honorable as that grand work unquestionably is. He and practical education " of the "industrial classes" alone \& novel and mighty and attractive as such work must have been to every statesman and every thinking man of his time, He came to aid Ezra Cornell in organ izing a "people's university," in the sense that it was to be a real, an all-embracing university, offering all the classes of people. He came to perform his splendid part in the erection of a true university ; the like of
which had been dreamed of, in misty and undefined form, by many a great soul in earlier days, but which had never before become concrete. This was work for a president of a great university that might wel even a greater work than that of making laws for the When Henry W. Sage built the Sage College for
When oven for the nation. Women, he added another element which brought Cornell University more nearly into perfect and complete form, which gave more nearly perfect symmetry tructure of this sort in the history of the world When the same strong hand aided the university in
its upbuilding by the erection of the Sage School of Philosophy, it was but another and grander approximation to that perfection and completeness. When and sibley and Mo often before working with White task, erected the library which stands, as a magnificent memorial of good, sought to be done, in the midst
of these great buildings and on the edge of our beautiful campus, he gave a great and radiant center to the evolved from the earlier educational chaos. The enlarged departments, and the growth of the
material and visible university, under the skillful guiding hands of the newly adjusted administration, promoted by the unprecedented labors of a still too small
faculty, came forward with astonishing rapidity to tive which the blind poet dreamed of as " complete and perfect."
How great the work here so well begun may be
inferred when it is said that, to educate the existing
body of American youth, as well as portions of the body of American youth, as well as portions of the men, there should be founded, in the United States, to-day, no less than twenty technical universities, fifty ing manual training and the "sloje" systems in their
curricula and preparation; while two thousand pro-
fessors, with twenty-five thousand students, twenty 